\title{
Systematic Review \\ Paraoxonase 1 and Chronic Obstructive Pulmonary Disease: A Meta-Analysis
}

\author{
Jun Watanabe ${ }^{1}\left(\mathbb{D}\right.$, Kazuhiko Kotani $^{1, *}(\mathbb{D})$ and Alejandro Gugliucci ${ }^{2}(\mathbb{D}$ \\ 1 Division of Community and Family Medicine, Jichi Medical University, Shimotsuke 329-0498, Japan; \\ m06105jw@jichi.ac.jp \\ 2 Glycation, Oxidation and Disease Laboratory, Touro University-California, Vallejo, CA 94592, USA; \\ agugliuc@touro.edu \\ * Correspondence: kazukotani@jichi.ac.jp; Tel.: +81-285-58-7394
}

Citation: Watanabe, J.; Kotani, K.; Gugliucci, A. Paraoxonase 1 and Chronic Obstructive Pulmonary Disease: A Meta-Analysis. Antioxidants 2021, 10, 1891. https:// doi.org/10.3390/antiox10121891

Academic Editor: Chul Gyu Yoo

Received: 26 October 2021

Accepted: 24 November 2021

Published: 26 November 2021

Publisher's Note: MDPI stays neutral with regard to jurisdictional claims in published maps and institutional affiliations.

Copyright: (c) 2021 by the authors. Licensee MDPI, Basel, Switzerland. This article is an open access article distributed under the terms and conditions of the Creative Commons Attribution (CC BY) license (https:// creativecommons.org/licenses/by/ $4.0 /)$.

\begin{abstract}
Oxidative stress is a driving factor in the pathophysiology of chronic obstructive pulmonary disease (COPD). While paraoxonase 1 (PON1) is an antioxidant enzyme and a potential biomarker of this disease, data regarding the status of PON-1 in COPD are inconclusive. In this regard, to shed light on this issue, we performed a meta-analysis of data on PON1 activity in COPD. Electronic databases (MEDLINE, Embase and CENTRAL) were searched for available studies on PON1 activity in patients with stable COPD published before October 2021. A meta-analysis was performed using random-effects models. Twelve studies (12 studies on paraoxonase and three on arylesterase) were identified. Patients with COPD had lower levels of paraoxonase activity (standard mean difference [SMD] $-0.77,95 \%$ confidence interval [CI] -1.35 to -0.18 ) and arylesterase activity (SMD $-1.15,95 \%$ $\mathrm{CI}-1.95$ to -0.36$)$ in comparison to healthy controls. In subgroup analyses, paraoxonase activity was lower in patients of studies as consisted of mainly non-severe COPD (SMD $-1.42,95 \%$ CI -2.04 to -0.79 ) and, by contrast, slightly higher in patients of studies including severe COPD (SMD 0.33, $95 \%$ CI 0.02 to 0.64 ) in comparison to healthy controls. Arylesterase activity showed a similar trend. Overall, PON1 activity was lower in patients with COPD, suggesting that PON1-related antioxidant defense is impaired in COPD. Future studies are warranted.
\end{abstract}

Keywords: antioxidant; arylesterase; chronic obstructive lung disease; reactive oxygen species; paraoxonase

\section{Introduction}

Chronic obstructive pulmonary disease (COPD), a progressive airway disorder, is a major cause of disability and death worldwide, and the number of patients is increasing [1]. Smoking and air pollution leading to increased inflammation and free radicals in the respiratory tract cause an increased burden of oxidative stress, which leads to the development and progression of COPD [2,3]. Oxidative stress is reported to induce structural changes in the essential components of the lung, including irreversible damage to both the parenchyma and airway wall [4]. In this process, various molecules, such as nucleic acids, lipids and proteins, are oxidized due to the respiratory burst of leukocytes (macrophages $(\mathrm{M} \varphi)$ and polymorphonuclear $(\mathrm{PMN})$ leukocytes [5]. Currently, oxidative stress is considered a crucial contributor to the pathophysiology of COPD [6-8].

The burden of oxidative stress is modified by the antioxidant balance. Paraoxonase 1 (PON1), which is known as an antioxidant enzyme, is composed of 354 amino acids with a molecular weight $43 \mathrm{kDa}$ and is encoded by the PON1 gene [9]. PON1 activity is determined by the substrates used to measure it, in particular, arylesterase (when using phenylacetate) and paraoxonase (when using paraoxon). PON1 is a high-density lipoprotein (HDL)associated lipolactonase that has promiscuous activity as an esterase [10-15]. Based on the antioxidant properties of PON1, there have been studies regarding the roles of PON1 in various disease entities, including cardiovascular disease, kidney failure, diabetes mellitus, 
neurological disorders, and sleep apnea $[11,12,16,17]$. While the relationship between PON1 and COPD is also of interest, the current data appear inconclusive.

To date, there is no general consensus on circulating PON1 activity in patients with COPD. Given the putative importance of PON1 as a biomarker of this disease, the present study aimed to explore PON1 activity in COPD via a meta-analysis of available clinical studies.

\section{Materials and Methods}

The present review was conducted in accordance with the reporting guidelines outlined by the Preferred Reporting Items for Systematic Reviews and Meta-Analysis, PRISMA [18]. This protocol was registered in PROSPERO (ID 286949).

A search of the MEDLINE, Embase and CENTRAL electronic databases was performed. The following keywords were applied to search for studies published before 2 October 2021: 'PON1', 'paraoxonase', 'arylesterase' and 'chronic obstructive pulmonary disease' were applied to the search (Appendix A). The inclusion criteria were clinical studies that focused on PON1 activity in patients with stable COPD in comparison to healthy controls. The exclusion criteria were studies without healthy controls or studies that focused on PON1 in asthma patients. There were no restrictions on language, country, observation period, or year of publication. The reference lists of eligible studies were searched.

First, all retrieved candidate articles were independently screened according to their titles and summaries. The full texts of potentially relevant summaries were independently evaluated for eligibility. Original articles that did not focus on PON1 in patients with COPD in comparison to healthy controls were excluded. An article was considered eligible when the two researchers were in agreement. The risk of bias was evaluated using the Newcastle-Ottawa Quality Rating Scale, NOS [19]. Then, a summary table for each article was extracted and created.

Meta-analyses were performed using random-effects models in Review Manager 5.4.1 (RevMan 2020, The Nordic Cochrane Centre, Copenhagen, Denmark) [20]. The standard mean difference (SMD) and 95\% confidence interval (CI) of paraoxonase and arylesterase activity were calculated. When missing data existed, standard deviations were calculated based on the methods of the Cochrane handbook [21]. Statistical heterogeneity was evaluated by visual inspection of forest plots and by calculating the $I^{2}$ statistic $\left(I^{2}\right.$ values of $0 \%$ to $40 \%$ : May not be important; $30 \%$ to $60 \%$ : May represent moderate heterogeneity; $50 \%$ to $90 \%$ : May represent substantial heterogeneity; $75 \%$ to $100 \%$ : Considerable heterogeneity) [21]. When heterogeneity was identified ( $I^{2}$ statistic $>50 \%$ ), the possible source of heterogeneity was examined in subgroup analyses of the severity of COPD (studies including severe COPD versus studies of mainly non-severe COPD). In the respective studies, the severity of COPD was defined according to Global Initiative for Chronic Obstructive Lung Disease criteria (https: / / goldcopd.org/ (accessed on 25 November 2021)) based on spirometry, symptoms, and exacerbations [21].

\section{Results}

Figure 1 shows the flow for the selection of literature that reported PON1 activity of patients with COPD. Of the 119 initially identified articles, 100 articles were excluded after screening of titles and abstracts. After screening of full-texts, six studies were excluded because six studies did not focus on PON1 activity of patients with COPD [22-27]. One study [28] was excluded because it included the same population as another study [29]. Finally, 12 studies were identified [13,14,28-37]. 

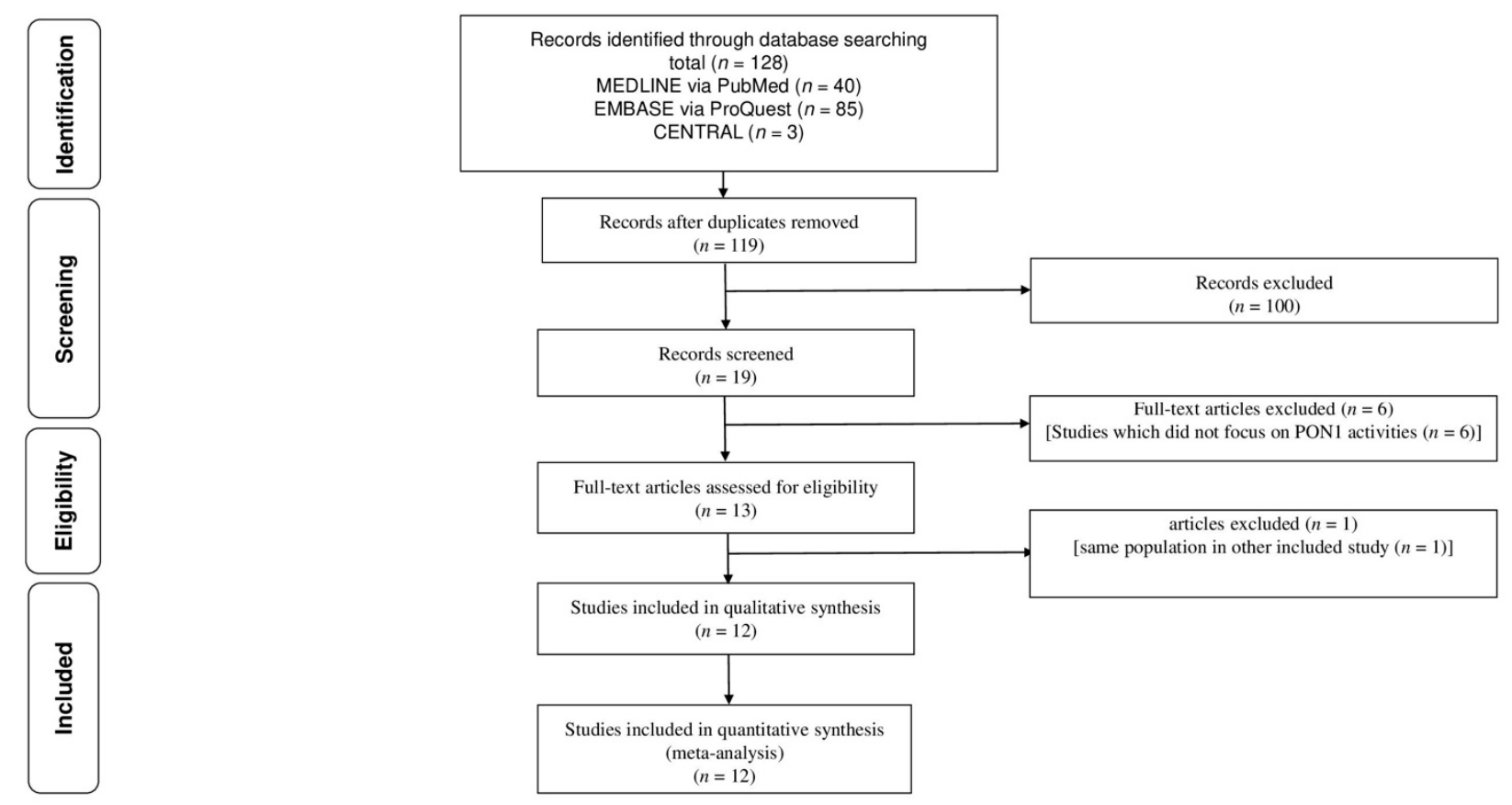

Figure 1. Flow of the selection of literature that reported the relationship of PON 1 with chronic obstructive pulmonary disease. PON1: paraoxonase 1.

Table 1 shows a summary of the included studies. Of the 12 studies, 12 measured paraoxonase activity $[13,14,28-37]$ and three measured arylesterase activity $[14,32,35]$. Four studies included patients with severe COPD (30-100\%) [13,14,28,34]. Table 2 shows the study quality of the included studies using the NOS (median score, 7; range, 5-8).

In the meta-analysis, as shown in Figure 2, paraoxonase activity of patients with COPD was significantly low in comparison to healthy controls (SMD, $-0.85 ; 95 \% \mathrm{CI},-1.41$ to $\left.-0.28 ; I^{2}=95 \%\right)$. As shown in Figure 3, arylesterase activity of patients with COPD was also significantly low in comparison to healthy patients (SMD, $-1.15 ; 95 \% \mathrm{CI},-1.95$ to $-0.36 ; I^{2}=91 \%$ ).

Table 1. Summary of the included articles on PON1 activity in patients with COPD.

\begin{tabular}{|c|c|c|c|c|c|c|c|}
\hline Authors [Ref No.] & Year & Country & Subject No. & Age & $\begin{array}{l}\text { Activity in } \\
\text { COPD }\end{array}$ & $\begin{array}{c}\text { Activity in Healthy } \\
\text { Controls }\end{array}$ & $\begin{array}{c}\text { Included Severe } \\
\text { COPD (\%) }\end{array}$ \\
\hline \multicolumn{8}{|l|}{ Paraoxonase } \\
\hline Isik [29] & 2005 & Turkey & 45 & 61 & $49.8 \pm 27.1$ & $107.8 \pm 36.3$ & NR \\
\hline Tekes [30] & 2010 & Turkey & 62 & 60 & $43.2 \pm 28.6$ & $100.8 \pm 40.3$ & NR \\
\hline Stanojkovic [13] & 2011 & Serbia & 74 & 63 & $447 \pm 337$ & $330 \pm 216$ & 100 \\
\hline Teke [31] & 2011 & Turkey & 25 & 63 & $96.8 \pm 57.4$ & $185.4 \pm 110.1$ & NR \\
\hline Acay [32] & 2013 & Turkey & 40 & 62 & $51.4 \pm 37.5$ & $521.4 \pm 156.2$ & NR \\
\hline Okur [33] & 2013 & Turkey & 11 & 57 & $124.6 \pm 28.4$ & $269.0 \pm 135.8$ & NR \\
\hline Soler [34] & 2013 & Spain & 110 & NR & $213.8 \pm 632.0$ & $271.0 \pm 1261.0$ & 38 \\
\hline Rumora [35] & 2014 & Croatia & 105 & 71 & $136.3 \pm 69.0$ & $194.6 \pm 98.2$ & NR \\
\hline Zinellu [36] & 2016 & Italy & 43 & 74 & $223.8 \pm 72.6$ & $253.0 \pm 71.5$ & 0 \\
\hline Arpaci [37] & 2018 & Turkey & 100 & NR & $28.5 \pm 14.9$ & $45.9 \pm 16.5$ & NR \\
\hline Sarioglu [14] & 2020 & Turkey & 66 & 64 & $199.1 \pm 134.5$ & $129.2 \pm 112.5$ & 30.3 \\
\hline Sepúlveda Loyola [28] & 2021 & Brazil & 39 & 69 & $186.0 \pm 55.5$ & $158 \pm 46.9$ & 54 \\
\hline \multicolumn{8}{|l|}{ Arylesterase } \\
\hline Acay [32] & 2013 & Turkey & 40 & 62 & $136.2 \pm 32.0$ & $198.4 \pm 50.2$ & 0 \\
\hline Rumora [35] & 2014 & Croatia & 105 & 71 & $21.2 \pm 10.3$ & $40.1 \pm 14.8$ & NR \\
\hline Sarioglu [14] & 2020 & Turkey & 66 & 64 & $21.3 \pm 14.9$ & $33.5 \pm 39.5$ & 30.3 \\
\hline
\end{tabular}

COPD, chronic obstructive pulmonary disease; NR, not reported; PON1, paraoxonase 1. 
Table 2. Study quality of the included studies.

\begin{tabular}{|c|c|c|c|c|c|c|c|c|c|}
\hline \multirow[b]{3}{*}{$\begin{array}{l}\text { Authors } \\
\text { [Ref No.] }\end{array}$} & \multicolumn{9}{|c|}{ The Newcastle-Ottawa Quality Assessment Scale } \\
\hline & \multicolumn{4}{|c|}{ Selection } & \multicolumn{2}{|l|}{ Comparability } & \multicolumn{2}{|l|}{ Outcome } & \multirow{2}{*}{$\begin{array}{l}\text { Total } \\
\\
\text { Score }\end{array}$} \\
\hline & $\begin{array}{l}\text { Representatives } \\
\text { of the Exposed } \\
\text { Cohort/ } \\
\text { Adequate Case } \\
\text { Definition } \\
(0,1)\end{array}$ & $\begin{array}{l}\text { Selection of } \\
\text { the Non- } \\
\text { Exposed } \\
\text { Cohort/ } \\
\text { Representative } \\
\text { of Cases } \\
(0,1)\end{array}$ & $\begin{array}{l}\text { Ascertainment } \\
\text { of Exposure/ } \\
\text { Selection of } \\
\text { Controls } \\
\quad(0,1)\end{array}$ & $\begin{array}{c}\text { Demonstration } \\
\text { That } \\
\text { Outcome of } \\
\text { Interest Was } \\
\text { Not Present } \\
\text { at Start of } \\
\text { Study/ } \\
\text { Definition } \\
\text { of Controls } \\
(0,1)\end{array}$ & $\begin{array}{l}\text { Comparability } \\
\text { on the Basis } \\
\text { of Design or } \\
\text { Analysis } \\
(0,1,2)\end{array}$ & $\begin{array}{c}\text { Assessment } \\
\text { of Outcome/ } \\
\text { Exposure } \\
(0,1)\end{array}$ & $\begin{array}{l}\text { Was } \\
\text { Follow-Up } \\
\text { Long } \\
\text { Enough for } \\
\text { Outcomes to } \\
\text { Occur }(0,1)\end{array}$ & $\begin{array}{l}\text { Adequacy } \\
\text { of Follow- } \\
\text { Up of } \\
\text { Cohorts } \\
(0,1)\end{array}$ & \\
\hline Isik [29] & 1 & 0 & 0 & 0 & 1 & 1 & 1 & 1 & 5 \\
\hline Tekes [30] & 1 & 0 & 0 & 0 & 1 & 1 & 1 & 1 & 5 \\
\hline Stanojkovic [13] & 1 & 1 & 1 & 1 & 1 & 1 & 1 & 1 & 8 \\
\hline Teke [31] & 1 & 0 & 0 & 0 & 1 & 1 & 1 & 1 & 5 \\
\hline Acay [32] & 1 & 0 & 1 & 1 & 1 & 1 & 1 & 1 & 7 \\
\hline Okur [33] & 1 & 0 & 1 & 1 & 1 & 1 & 1 & 1 & 7 \\
\hline Soler [34] & 1 & 1 & 1 & 0 & 1 & 1 & 1 & 1 & 7 \\
\hline Rumora [35] & 1 & 0 & 1 & 1 & 1 & 1 & 1 & 1 & 7 \\
\hline Zinellu [36] & 1 & 1 & 1 & 1 & 1 & 1 & 1 & 1 & 8 \\
\hline Arpaci [37] & 1 & 0 & 1 & 0 & 1 & 1 & 1 & 1 & 6 \\
\hline Sarioglu [14] & 1 & 1 & 1 & 1 & 1 & 1 & 1 & 1 & 8 \\
\hline $\begin{array}{l}\text { Sepúlveda } \\
\text { Loyola [28] }\end{array}$ & 1 & 1 & 1 & 1 & 1 & 1 & 1 & 1 & 8 \\
\hline
\end{tabular}

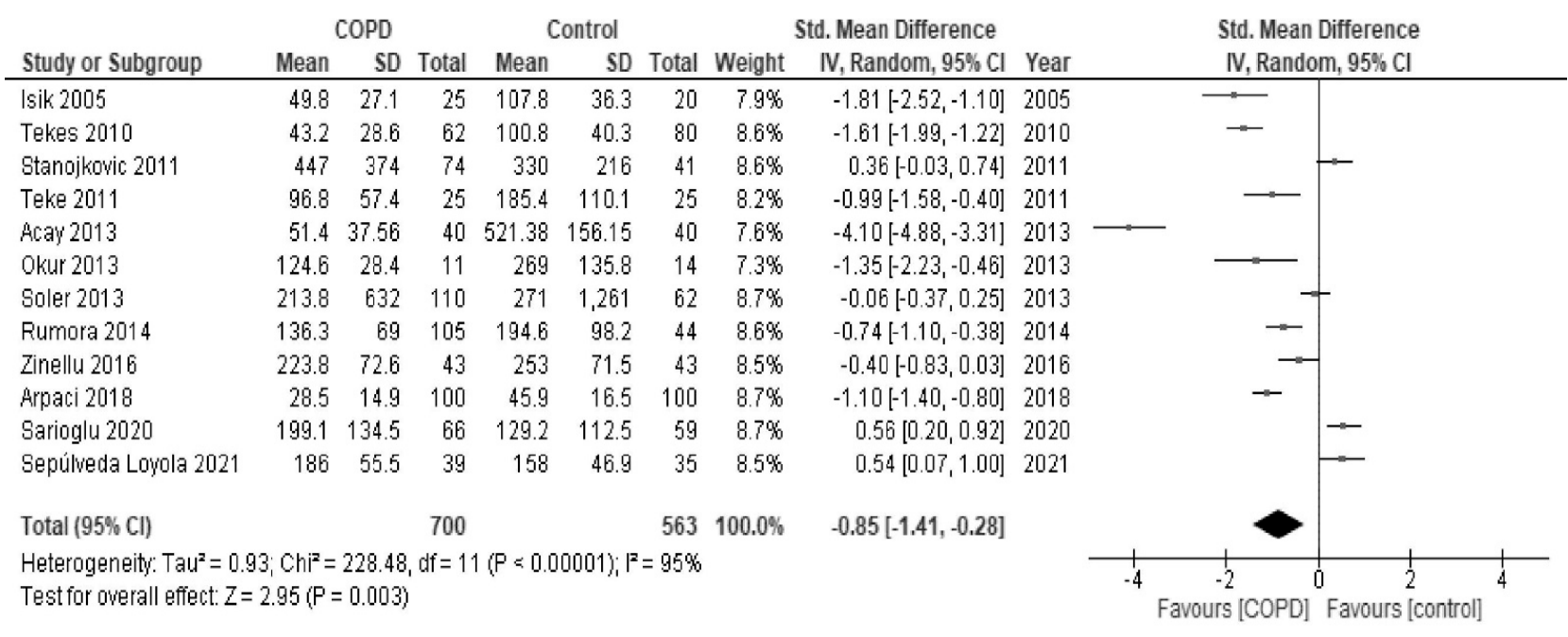

Figure 2. Forest plot of paraoxonase activity in all studies. COPD: chronic obstructive pulmonary disease; Std: standard; SD: standard deviation; CI: confidence interval; IV: interval variable.

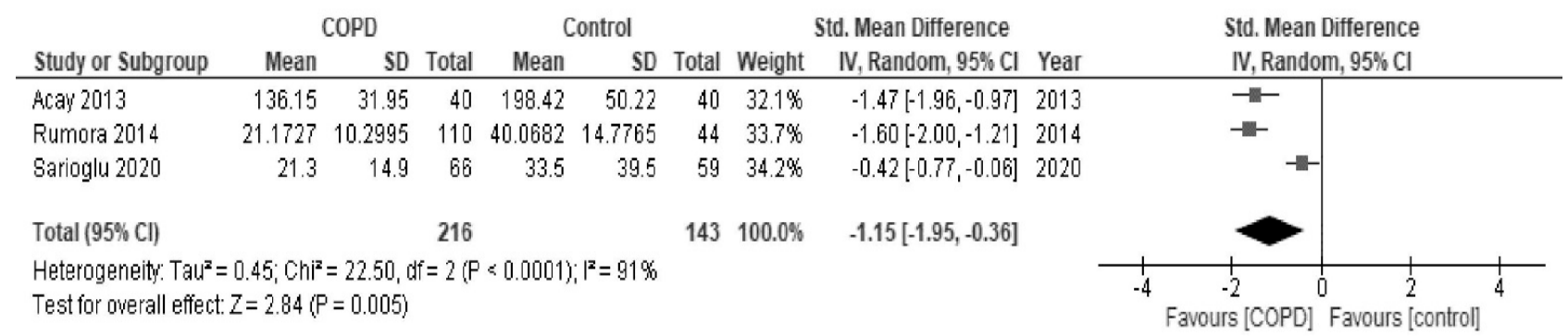

Figure 3. Forest plot of arylesterase activity in all studies.

In subgroup analyses by the severity of COPD, paraoxonase activity was found to be significantly low in studies that mainly included patients with non-severe COPD (SMD, $-1.46 ; 95 \% \mathrm{CI},-2.03$ to $-0.89 ; I^{2}=91 \%$ ) and, in contrast, was slightly but significantly higher in studies that included patients with severe COPD (SMD, 0.33; 95\% CI, 0.02 to $0.64 ; \mathrm{I}^{2}=64 \%$ ) in comparison to healthy controls (Figure 4 ). Arylesterase activity showed a similar trend (Figure 5). 


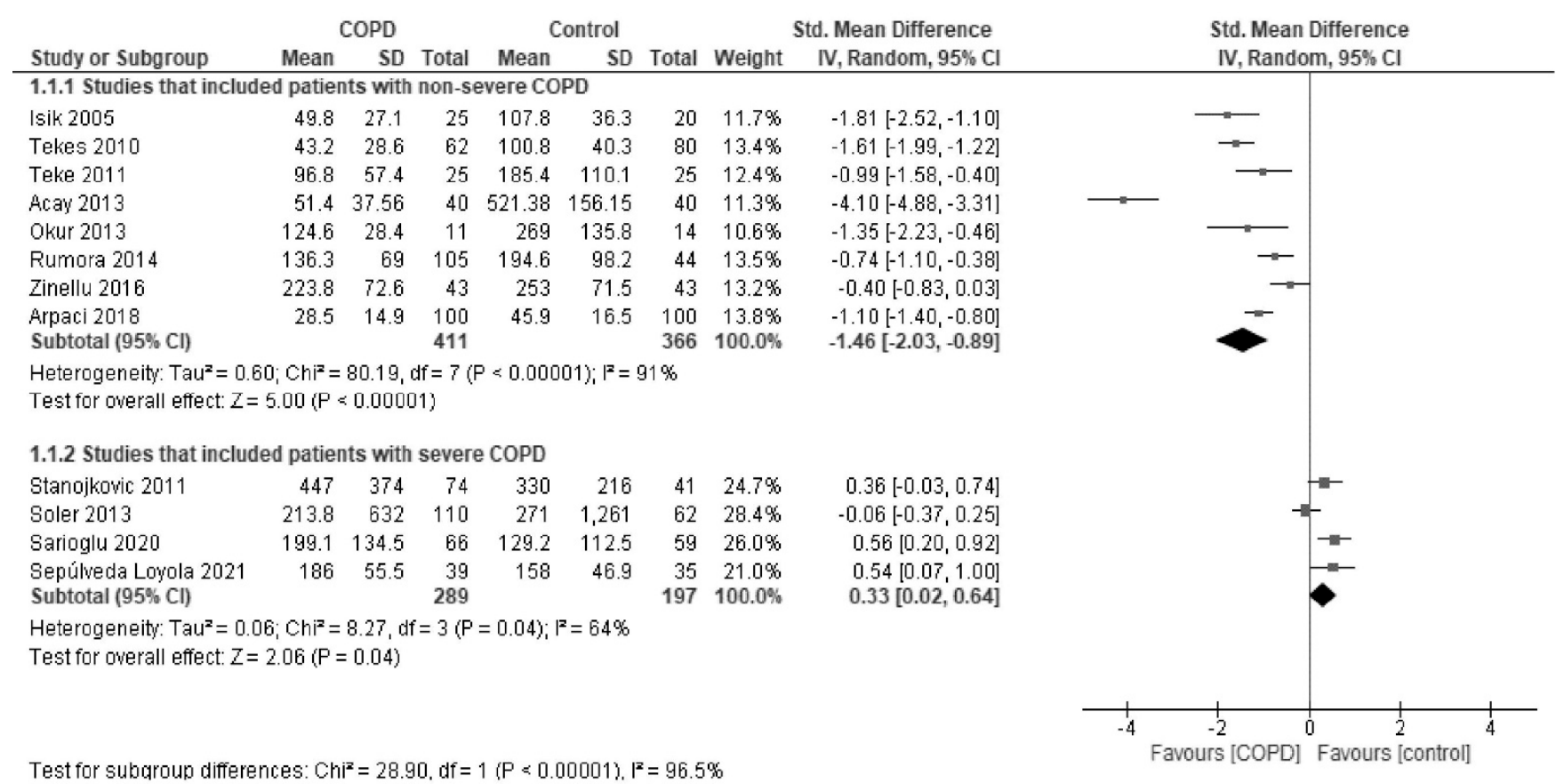

Figure 4. Forest plot of paraoxonase activity stratified by the severity of COPD.

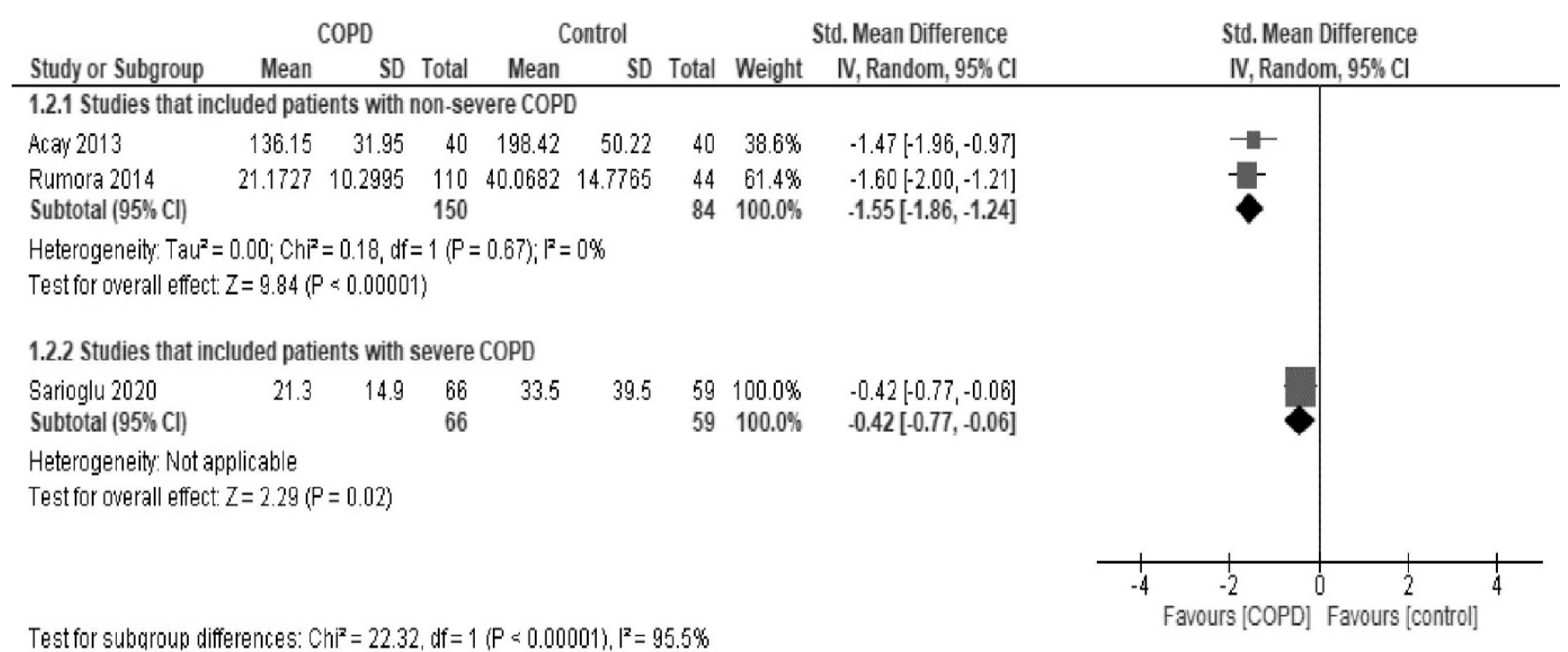

Figure 5. Forest plot of arylesterase activity stratified by the severity of COPD.

Some studies [14,28,32-35] reported the HDL-cholesterol (HDL-C) level in addition to PON1 activity. One study that included patients with severe COPD showed low levels of HDL-C [14], while another study showed high levels of HDL-C [28]. In three other studies that mainly included patients with non-severe COPD, the HDL-C levels were high [32-35]. The HDL-C levels did not differ according to the severity of COPD (test for subgroup differences: $p=0.85$ ), as shown in Figure 6 . 


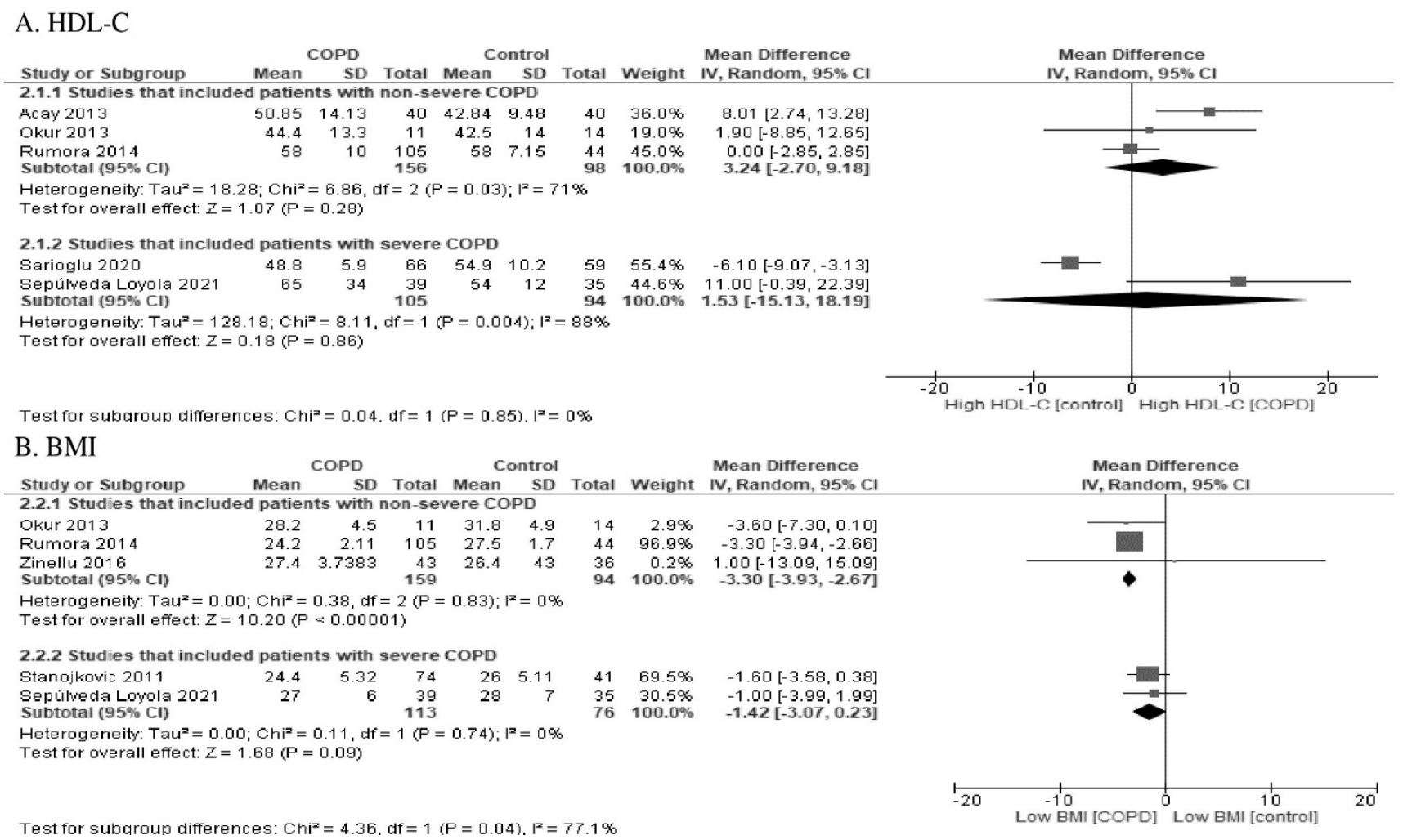

Figure 6. Forest plot of (A) high-density lipoprotein cholesterol and (B) body mass index stratified by the severity of COPD.

Some studies $[13,28,33,35,36]$ reported the body mass index (BMI) in addition to PON1 activity. The BMI was higher in studies that included patients with severe COPD $[13,28]$ in comparison to those that mainly included patients with non-severe COPD $[33,35,36]$ $(p=0.04)$, as shown in Figure 6.

\section{Discussion}

The present study demonstrated that, overall, both paraoxonase and arylesterase activities of PON1 were lower in COPD patients in comparison to healthy controls. In addition, this lower paraoxonase activity was observed in studies that mainly included patients with non-severe COPD, but not in studies that included patients with severe COPD. Arylesterase activity also showed a similar trend. These results indicate that COPD could be generally associated with impaired PON1 activity. This implies an impaired antioxidant defense in COPD, and the measurement of PON1 activity can be useful to explore the oxidative stress-related pathophysiology of COPD.

COPD, which produces chronic oxidative stress generated by hypoxia and single electron reduction of oxygen, is hypothesized to promote both catabolism and inactivation of PON1 molecules [38,39]; accordingly, it may partly explain the low PON1 activity observed in the present study. Although paraoxonase activity (using paraoxon as a substrate) and arylesterase activity (using phenylacetate as a substrate) can differ depending on the multiple polymorphisms of PON 1 [11,12], both activities often show changes on the same direction $[11,12]$. Therefore, it is not surprising to find that paraoxonase and arylesterase activities show similar trends in COPD.

The present study raises the possibility that mild- and moderate-grade COPD may be associated with lower PON1 activity and paradoxically, severe COPD might be associated with slightly higher activity. Although the reason why PON1 activity differed according to the severity of COPD are unclear, we can suggest as a main explanation the status of alveolar infiltration of $\mathrm{M} \varphi$ and PMNs which is higher in earlier stages. Indeed, myeloperoxidase (MPO) stemming from these cells is a critical PON1 inactivator [40,41]. In later stages of 
COPD when most parenchyma is destroyed, one expects less contact of PON1 with MPO, then less inactivation. As smoking cessation increases the levels of HDL-C and PON1 due to relief of the oxidative burden [42], patients with severe COPD could fare better due to smoking cessation Another possibility is that when the disease reaches a severe state with compromised hematosis, a compensatory effect on PON1 synthesis might ensue. Patients with severe COPD generally have oxygen therapy, an antioxidant therapy [21], which could prevent enhancement of catabolism and inactivation of PON1. Finally, as mortality increases with the progression of the severity of COPD [43], patients with severe COPD who have relatively higher PON1 activities may survive (called the 'survival effect' or 'reverse causality'). According to the results of the present study and our hypotheses, further studies are needed to examine the relationship between PON1 and the severity of COPD.

The present study has some limitations. Although we searched the three main electronic databases, the number of studies included in this review was relatively small. PON1 activity is affected by lifestyle factors, such as diet and exercise. None of the studies included in the present meta-analysis examined the effects of lifestyle. Although PON1 activity is affected by polymorphism [11,12], no studies on polymorphisms were found. There are ethnic differences in lifestyle factors and polymorphisms, but we had insufficient ethnic data in the present study to confirm this issue. Stratification of COPD by severity (including studies of severe COPD versus studies of mainly non-severe COPD) may be flawed since the studies included did not always determine objectively the severity of the patients. Cohort studies and intervention studies were not performed to investigate the relationship of PON1 with COPD. The range of PON1 measurements was large because of poor standardization of methods. Since the low PON1 activity found in the present study, may be the result of low PON1 protein mass, no studies that measured PON1 mass were found. This will be addressed in future studies.

\section{Conclusions}

The present study revealed, via a meta-analysis, that, overall, PON1 activity was lower in patients with COPD. This suggests an impaired PON1-related antioxidant defense; therefore, PON1 activity can become a useful biomarker for the assessment of the oxidative stress burden in COPD. PON1 activity may be used for COPD management if data regarding a prognostic dimension of PON1 are accumulated in patients with COPD. Future studies are called for.

Author Contributions: Conceptualization, J.W. and K.K.; Methodology, J.W. and K.K.; Software, J.W.; Validation, J.W. and K.K.; Formal Analysis, J.W.; Investigation, J.W. and K.K.; Resources, N/A; Data Curation, J.W. and K.K.; Writing-Original Draft Preparation, J.W.; Writing-Review and Editing, K.K and A.G.; Visualization, J.W.; Supervision, K.K. and A.G.; Project Administration, K.K. All authors have read and agreed to the published version of the manuscript.

Funding: This research received no external funding.

Conflicts of Interest: The authors declare no conflict of interest in association with the present study.

\section{Appendix A}

MEDLINE via PubMed

\#1. “Aryldialkylphosphatase"[Mesh]

\#2. "aryldialkylphosphatase" [tiab]

\#3. "arylesterase" [tiab]

\#4. "paraoxonase" ${ }^{\prime}[$ tiab]

\#5. \#1 OR \#2 OR \#3 OR \#4

\#6. “Lung Diseases, Obstructive"[Mesh]

\#7. "Pulmonary Disease, Chronic Obstructive"[Mesh]

\#8. emphysema*[tiab]

\#9. chronic*[tiab] AND bronchiti*[tiab] 
\#10. obstruct*[tiab] AND (pulmonary[tiab] OR lung*[tiab] OR airway*[tiab] OR aiflow*[tiab] OR bronch*[tiab] OR respirat*[tiab])

\#11. COPD[tiab] OR COAD[tiab] OR COBD[tiab] OR AECB[tiab]

\#12. \#6 OR \#7 OR \#8 OR \#9 OR \#10 OR \#11

\#13. \#5 AND \#12

CENTRAL via Cochrane Library

\#1. MeSH descriptor: [Aryldialkylphosphatase] explode all trees

\#2. aryldialkylphosphatase:ti,ab,kw (Word variations have been searched)

\#3. arylesterase:ti,ab,kw (Word variations have been searched)

\#4. paraoxonase:ti,ab, $\mathrm{kw}$ (Word variations have been searched)

\#5. \#1 OR \#2 OR \#3 OR \#4

\#6. MeSH descriptor: [Lung Diseases, Obstructive] explode all trees

\#7. MeSH descriptor: [Pulmonary Disease, Chronic Obstructive] explode all trees

\#8. emphysema*:ti,ab,kw (Word variations have been searched)

\#9. (chronic* AND bronchiti*):ti,ab,kw (Word variations have been searched)

\#10. (obstruct* AND (pulmonary OR lung* OR airway* OR airflow* OR bronch* OR respirat*):ti,ab, $\mathrm{kw}$ (Word variations have been searched)

\#11. (COPD OR COAD OR COBD OR AECB):ti,ab,kw (Word variations have been searched)

\#12. \#6 OR \#7 OR \#8 OR \#9 OR \#10 OR \#11

\#13. \#5 AND \#12

Embase via Proquest

S1 EMB.EXACT.EXPLODE("aryldialkylphosphatase")

S2 ab(aryldialkylphosphatase) OR ti(aryldialkylphosphatase)

S3 ab(arylesterase) OR ti(arylesterase)

$\mathrm{S} 4 \mathrm{ab}$ (paraoxonase) OR ti(paraoxonase)

S5 S1 OR S2 OR S3 OR S4

S6 EMB.EXACT.EXPLODE("obstructive lung disease")

S7 EMB.EXACT.EXPLODE("chronic obstructive lung disease")

S8 ab(emphysema*) OR ti(emphysema*)

S9 EMB.EXACT.EXPLODE("chronic obstructive lung disease")

S10 ab(emphysema*) OR ti(emphysema*)

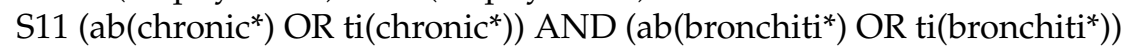

S12 (ab(obstruct*) OR ti(obstruct*)) AND ((ab(pulmonary) OR ti(pulmonary)) OR

(ab(lung*) OR ti(lung*)) OR (ab(airway*) OR ti (airway*)) OR (ab(bronch*) OR ti(bronch*))

OR (ab(respirat*) OR ti(respirat*)))

S13 (ab(COPD) OR ti(COPD)) OR (ab(COAD) OR ti(COAD)) OR (ab(COBD) OR ti(COBD)) OR (ab(AECB) OR ti(AECB))

S14 S6 OR S7 OR S8 OR S9 OR S10 OR S11 OR S12 OR S13

S15 S5 AND S14

\section{References}

1. GBD Chronic Respiratory Disease Collaborators. Prevalence and attributable health burden of chronic respiratory diseases, 1990-2017: A systematic analysis for the Global Burden of Disease Study 2017. Lancet Respir. Med. 2020, 8, 585-596. [CrossRef]

2. Comandini, A.; Rogliani, P.; Nunziata, A.; Cazzola, M.; Curradi, G.; Saltini, C. Biomarkers of lung damage associated with tobacco smoke in induced sputum. Respir. Med. 2009, 103, 1592-1613. [CrossRef]

3. Lewis, B.W.; Ford, M.L.; Rogers, L.K.; Britt, R.D., Jr. Oxidative Stress Promotes Corticosteroid Insensitivity in Asthma and COPD. Antioxidants 2021, 10, 1335. [CrossRef]

4. Drost, E.M.; Skwarski, K.M.; Sauleda, J.; Soler, N.; Roca, J.; Agusti, A.; MacNee, W. Oxidative stress and airway inflammation in severe exacerbations of COPD. Thorax 2005, 60, 293-300. [CrossRef]

5. Chung, K.F;; Adcock, I.M. Multifaceted mechanisms in COPD: Inflammation, immunity, and tissue repair and destruction. Eur. Respir. J. 2008, 31, 1334-1356. [CrossRef]

6. MacNee, W. Oxidants/antioxidants and COPD. Chest 2000, 117, 303S-317S. [CrossRef] [PubMed]

7. Barnes, P.J.; Shapiro, S.D.; Pauwels, R.A. Chronic obstructive pulmonary disease: Molecular and cellular mechanisms. Eur. Respir. J. 2003, 22, 672-688. [CrossRef] [PubMed] 
8. Zinellu, E.; Zinellu, A.; Fois, A.G.; Fois, S.S.; Piras, B.; Carru, C.; Pirina, P. Reliability and Usefulness of Different Biomarkers of Oxidative Stress in Chronic Obstructive Pulmonary Disease. Oxid. Med. Cell Longev. 2020, 2020, 4982324. [CrossRef]

9. Soran, H.; Younis, N.N.; Charlton-Menys, V.; Durrington, P. Variation in paraoxonase-1 activity and atherosclerosis. Curr. Opin. Lipidol. 2009, 20, 265-274. [CrossRef]

10. Mackness, M.I.; Arrol, S.; Durrington, P.N. Paraoxonase prevents accumulation of lipoperoxides in low-density lipoprotein. FEBS Lett. 1991, 286, 152-154. [CrossRef]

11. Aviram, M.; Rosenblat, M.; Billecke, S.; Erogul, J.; Sorenson, R.; Bisgaier, C.L.; Newton, R.S.; La Du, B. Human serum paraoxonase (PON 1) is inactivated by oxidized low density lipoprotein and preserved by antioxidants. Free Radic. Biol. Med. 1999, 26, 892-904. [CrossRef]

12. Camps, J.; Marsillach, J.; Joven, J. The paraoxonases: Role in human diseases and methodological difficulties in measurement. Crit. Rev. Clin. Lab. Sci. 2009, 46, 83-106. [CrossRef] [PubMed]

13. Stanojkovic, I.; Kotur-Stevuljevic, J.; Milenkovic, B.; Spasic, S.; Vujic, T.; Stefanovic, A.; Llic, A.; Ivanisevic, J. Pulmonary function, oxidative stress and inflammatory markers in severe COPD exacerbation. Respir. Med. 2011, 105, S31-S37. [CrossRef]

14. Sarioglu, N.; Bilen, C.; Cevik, C.; Gencer, N. Paraoxonase Activity and Phenotype Distribution in Patients with Chronic Obstructive Pulmonary Disease. Eurasian J. Med. 2020, 52, 161-165. [CrossRef] [PubMed]

15. Sepúlveda-Loyola, W.; de Castro, L.A.; Matsumoto, A.K.; Camillo, C.A.; Barbosa, D.S.; Galvan, C.C.R.; Probst, V.S. NOVEL antioxidant and oxidant biomarkers related to sarcopenia in COPD. Heart Lung 2021, 50, 184-191. [CrossRef]

16. rła-Kaján, J.; Jakubowski, H. Paraoxonase 1 and homocysteine metabolism. Amino Acids 2012, 43, 1405-1417. [CrossRef] [PubMed]

17. Gugliucci, A.; Kotani, K.; Kimura, S. Paraoxonase 1 in chronic kidney failure. J. Lipids. 2012, 2012, 726048. [CrossRef]

18. Page, M.J.; McKenzie, J.E.; Bossuyt, P.M.; Boutron, I.; Hoffmann, T.C.; Mulrow, C.D.; Shamseer, L.; Tetzlaff, J.M.; Akl, E.A.; Brennan, S.E.; et al. The PRISMA 2020 statement: An updated guideline for reporting systematic reviews. BMJ 2021, 372 , n71. [CrossRef]

19. Wells, G.; Shea, B.; O'Connell, D.; Peterson, J.; Welch, V.; Losos, M.; Tugwell, P. The Newcastle-Ottawa Scale (NOS) was used to assess the quality of nonrandomized studies in meta-analyses. 2011. Available online: http://www.ohri.ca/programs/clinical_ epidemiology / oxford.asp (accessed on 9 October 2021).

20. Higgins, J.P.T.; Thomas, J. Cochrane Handbook for Systematic Reviews of Interventions Version 6.2, 2021. Cochrane; Wiley: Hoboken, NJ, USA, 2021.

21. Torres-Ramos, Y.D.; Guzman-Grenfell, A.M.; Montoya-Estrada, A.; Ramirez-Venegas, A.; Martinez, R.S.; Flores-Trujillo, F.; Ochoa-Cautino, L.; Hicks, J.J. RBC membrane damage and decreased band 3 phospho-tyrosine phosphatase activity are markers of COPD progression. Front. Biosci. 2010, 2, 1385-1393.

22. Cho, K.H.; Kim, Y.S.; Nam, C.M.; Kim, T.H.; Kim, S.J.; Han, K.T.; Park, E.C. Home oxygen therapy reduces risk of hospitalisation in patients with chronic obstructive pulmonary disease: A population-based retrospective cohort study, 2005-2012. BMJ Open 2015, 5, e009065. [CrossRef]

23. Gürbüz, Ş.; Yıldız, M.; Kara, M.; Kargün, K.; Gürger, M.; Ateşçelik, M.; Alataş, Ö.D. Paraoxonase-1 gene in patients with chronic obstructive pulmonary disease investigation Q192R and L55M polymorphisms. World J. Emerg. Med. 2015, 6, 201-206. [CrossRef]

24. Erbay, Ü.T.; Ayada, C.; Simsek, H.; Arik, Ö. Can total thiol be a new parameter for the diagnosis of copd? Acta Physiol. 2017, 221,66 .

25. Sotgiu, E.; Ena, S.; Assaretti, S.; Arru, D.; Baralla, A.; Zinellu, E.; Fois, A.G.; Pirina, P.; Zinellu, A.; Carru, C. Oxidative stress and arginines plasma levels in not severe COPD. Clin. Chem. Lab. Med. 2017, 55, S771.

26. Grdić Rajković, M.; Popović-Grle, S.; Vukić Dugac, A.; Rogić, D.; Rako, I.; Radić Antolić, M.; Beriša, M.; Rumora, L. PON1 gene polymorphisms in patients with chronic obstructive pulmonary disease. J. Clin. Pathol. 2018, 71, 963-970. [CrossRef] [PubMed]

27. Lv, M.; Sun, D.; Chen, L. Identification of Prognostic Value of Rs3735590 Polymorphism in 3'-Untranslated Region (3'-UTR) of Paraoxonase 1 (PON-1) in Chronic Obstructive Pulmonary Disease Patients who Received Coronary Artery Bypass Grafting (CABG). Cell Physiol. Biochem. 2018, 47, 1809-1818. [CrossRef] [PubMed]

28. Sepúlveda Loyola, W.A.; Vilaça Cavallari Machado, F.; Araújo de Castro, L.; Hissnauer Leal Baltus, T.; Rampazzo Morelli, N.; Landucci Bonifácio, K.; Morita, A.A.; Michelin, A.P.; Sabbatini Barbosa, D.; Probst, V.S. Is oxidative stress associated with disease severity, pulmonary function and metabolic syndrome in chronic obstructive pulmonary disease? Rev. Clin. Esp. 2019, 219, 477-484. [CrossRef]

29. Isik, B.; Isik, R.S.; Ceylan, A.; Calik, O. Trace elements and oxidative stress in chronic obstructive pulmonary disease. Saudi. Med. J. 2005, 26, 1882-1885.

30. Tekes, S.; Isik, B.; Yildiz, T.; Simsek, S.; Isik, M.R.; Budak, T. Chronic Obstructive Pulmonary Disease and Paraoxonase-1 192 and 55 Gene Polymorphisms. Biotechnol. Biotechnol. Equip. 2010, 24, 1644-1647. [CrossRef]

31. Teke, T.; Maden, E.; Kiyici, A.; Bekci, T.T.; Erdem, S.S.; Tosun, M.; Uzun, K. Paraoxonase activity in patients with COPD. Eur. Respir. J. 2011, 38, 3897.

32. Acay, A.; Erdenen, F.; Altunoglu, E.; Erman, H.; Muderrisoglu, C.; Korkmaz, G.G.; Gelisgen, R.; Tabak, O.; Uzun, H. Evaluation of serum paraoxonase and arylesterase activities in subjects with asthma and chronic obstructive lung disease. Clin. Lab. 2013, 59, 1331-1337. [CrossRef]

33. Okur, H.K.; Pelin, Z.; Yuksel, M.; Yosunkaya, S. Lipid peroxidation and paraoxonase activity in nocturnal cyclic and sustained intermittent hypoxia. Sleep Breath. 2013, 17, 365-371. [CrossRef] 
34. Soler, N.; García-Heredia, A.; Marsillach, J.; Mackness, B.; Mackness, M.; Joven, J.; Romero, P.; Camps, J. Paraoxonase-1 is associated with corneal endothelial cell alterations in patients with chronic obstructive pulmonary disease. Invest. Ophthalmol. Vis. Sci. 2013, 54, 5852-5858. [CrossRef] [PubMed]

35. Rumora, L.; Rajković, M.G.; Kopčinović, L.M.; Pancirov, D.; Čepelak, I.; Grubišić, T.Ž. Paraoxonase 1 activity in patients with chronic obstructive pulmonary disease. COPD 2014, 11, 539-545. [CrossRef] [PubMed]

36. Zinellu, A.; Fois, A.G.; Sotgia, S.; Sotgiu, E.; Zinellu, E.; Bifulco, F.; Mangoni, A.A.; Pirina, P.; Carru, C. Arginines Plasma Concentration and Oxidative Stress in Mild to Moderate COPD. PLoS ONE 2016, 11, e0160237. [CrossRef] [PubMed]

37. Arpaci, A.; Yalin, S.; Taskin, D.; Fakioglu, F.; Ulutas, K.T.; Comelekoglu, U. Investigation of antioxidant enzyme polymorphism in chronic obstructive pulmonary disease patients. Biomed. Res. 2018, 29, 1906-1913. [CrossRef]

38. Mahrooz, A.; Mackness, M. Epigenetics of paraoxonases. Curr. Opin. Lipidol. 2020, 31, 200-205. [CrossRef]

39. Costa, L.G.; Vitalone, A.; Cole, T.B.; Furlong, C.E. Modulation of paraoxonase (PON1) activity. Biochem. Pharmacol. 2005, 69, 541-550. [CrossRef]

40. Huang, Y.; Wu, Z.; Riwanto, M.; Gao, S.; Levison, B.S.; Gu, X.; Fu, X.; Wagner, M.A.; Besler, C.; Gerstenecker, G. Myeloperoxidase, paraoxonase-1, and HDL form a functional ternary complex. J. Clin. Invest. 2013, 123, 3815-3828. [CrossRef]

41. Bacchetti, T.; Ferretti, G.; Carbone, F.; Ministrini, S. Dysfunctional high-density lipoprotein: The role of myeloperoxidase and paraoxonase-1. Curr. Med. Chem. 2021, 28, 2842-2850. [CrossRef]

42. Riley, C.M.; Sciurba, F.C. Diagnosis and Outpatient Management of Chronic Obstructive Pulmonary Disease: A Review. JAMA 2019, 321, 786-797. [CrossRef]

43. Sansbury, L.B.; Rothnie, K.J.; Bains, C.; Compton, C.; Anley, G.; Ismaila, A.S. Healthcare, Medication Utilization and Outcomes of Patients with COPD by GOLD Classification in England. Int. J. Chron. Obstruct. Pulmon. Dis. 2021, 16, 2591-2604. [CrossRef] [PubMed] 